\title{
PROSTATE SPECIFIC ANTIGEN VERSUS COMBINATION OF PROSTATE SPECIFIC ANTIGEN AND ALKALINE PHOSPHATASE IN PREDICTION OF PROSTATE CARCINOMA BONE METASTASES DETECTED WITH BONE SCINTIGRAPHY
}

\author{
Miloš Stević1,2, Marina Vlajković1,2, Marko Kojić ${ }^{1}$, Filip Veličković ${ }^{1}$, Nina Topić1, \\ Dragoslav Bašićc ${ }^{2,3}$
}

\begin{abstract}
Prostate cancer (PC) is the second one in morbidity and mortality in a population of men over 50 and has a high affinity for metastasis to the bone system. The aim of this study was to determine predictive value of prostate specific antigen (PSA) versus to combination of PSA and alkaline phosphatase (ALP) for existence of skeletal PC metastases. The study included 620 patients with histologically proven PC with elevated PSA, ALP, or clinical signs that indicated bone metastases. Bone scintigraphy (BS) was performed according to the protocol of the European Association of Nuclear Medicine. Specificity, sensitivity, positive and negative predictive value, and overall accuracy of PSA and the combination of PSA and ALP were evaluated in predicting the existence bone metastases on BS. The PSA showed sensitivity of $91.88 \%$; specificity of $37.5 \%$; positive predictive value of $53.32 \%$; a negative predictive value of $85.62 \%$ and an overall accuracy of $61.22 \%(95 \%$ CI). The PSA and ALP combination showed a sensitivity of $99.20 \%$, specificity of $96.88 \%$, positive predictive value of $98.41 \%$, and negative predictive value of $98.41 \%$ and an overall accuracy of $98.41 \%(95 \% \mathrm{CI})$. The combination of PSA and ALP showed significantly higher sensitivity, specificity, positive and negative predictive value and overall accuracy than the PSA only. When indicating BS in patients with PC, PSA, ALP, and clinical signs should be evaluated for the early detection of bone metastases and in the aim to avoid unnecessary admission to scintigraphy of patients in whom there is no high suspicion of bone metastases.
\end{abstract}

Acta Medica Medianae 2020;59(3):73-83.

Key words: prostate specific antigen, alkaline phosphatase, bone scintigraphy

${ }_{1}^{1}$ Clinical Center Niš, Center of Nuclear Medicine, Niš, Serbia
${ }^{2}$ University of Niš, Faculty of Medicine, Niš, Serbia

${ }^{3}$ Clinical Center Niš, Clinic for Urology, Niš, Serbia

Contact: Miloš Stević

8/68 Prešernova St., 18000 Niš, Serbia

E-mail: mlsstvc@gmail.com

\section{Introduction}

Prostate cancer (PC) ranks second in both, morbidity and mortality in a population of men over 50 , with a median age of patients of 66 years at the time of initial diagnosis (1). Prostate cancer in its initial stages is often a completely asymptomatic di- sease. The symptoms that may indicate that there may be changes in the prostate in terms of an incipient prostate cancer are mainly problems associated with urination, such as difficult or frequent urination, or the need for urination that occurs during the night. Sometimes the initial symptoms are pain in the lumbar spine, which is encounter-edusually in advanced stages of the disease, precisely because the axial skeleton is most often affected by metastatic prostate cancer.

Suspicion of the existence of the disease is usually based on elevated serum prostate specific antigen (PSA) values greater than $4 \mathrm{ng} / \mathrm{mL}$. Increased PSA level is also mixed in other conditions associated with prostate disorders such as benign prostatic hyperplasia (BHP). For diagnosis of PC, the basic diagnostic method is biopsy and histological findings.

Prostate cancer metastases mainly occur in the skeleton and represent a very important prognostic indicator, and very important factor in planning of a therapeutic approach in patients diagnosed with PC (2). 
Bone scintigraphy is still the most commonly used method for detecting the existence of PC bone metastases. However, BS cannot be used as a screening method for the detection of metastatic disease of any oncological entity, even in the case of PC.

The indication for BS for the detection of PC metastases is mainly related to elevated PSA values. However, elevated PSA alone does not necessarily indicate bone metastases, which would mean that a certain group of patients would needlessly be referred for BS examination.

The clinical picture of patients, especially the presence of the pain in the axial skeleton or other parts of the locomotor system, also does not represent a safe indication for BS examination, considering that the average detection time of PC is 66 years of age, and those kind of clinical signs are usual in this population of men even without PC.

One of the biochemical markers that should be used together with PSA is alkaline phosphatase $(A L P)$. Alkaline phosphatase is released mainly in the liver and skeletal system, and elevated ALP values in patients with PC in the absence of liver disease are largely originated in the skeleton (3).

\section{The aim}

The focus of this study was the assessment of accuracy in prediction of bone metastasis in patients with PC using the combination of values of PSA, ALP and the existence of clinical signs, versus the prediction achieved using levels of PSA only as an independent predictor for the existence of skeletal metastases of PC.

\section{Patients and methodology}

Six hundred twenty patients, from 51 to 91 years of age, were examined (average 71 years of age SD 7.012). All patients were diagnosed with biopsy and histopathological findings. Laboratory analysis of serum PSA and ALP levels was performed in all patients. All patients with elevated PSA, ALP and with clinical signs such was the presence of the pain predominantly in the axial skeleton or in some other parts of skeleton, underwent BS.

PSA was determined on UniCel DxI 600 (BECKMAN COULTER) with Hybritec PSA Chemiluminiscent Immunoassay, with normal values in the range from 0.0 to $4.0 \mathrm{ng} / \mathrm{mL}$.

The ALP was determined on UniCel Dxl 600 (BECKMAN COULTER), Chemiluminescent Immunoassay with a reference range from 20 to $140 \mathrm{IU} / \mathrm{L}$.

Bone scintigraphy was performed according to the standard protocol recommended by the European Nuclear Medicine Association (4) on a Siemens dual-head gamma camera, in "whole body" (WBS) modality, or "spot" static scintigrams and/or single photon emission tomography (SPECT) modality when lesions detected on the WBS were suspected but not clear for the existence of secondary deposits. Whole body scintigrams in AP and PA projections were made in one pass, with a recording speed of $12 \mathrm{~cm} / \mathrm{min}$ in anterior (AP) and posterior (PA) projections with computerized "zipping" of the scintigraphic image, in order to get a full skeleton view in one act. Targeted spot static scintigrams were made in AP and PA projections over the region of interest which was the region where suspected scintigraphic signs of lesions corresponding to secondary deposits were observed on WBS scintigrams. The SPECT method was applied over the suspected regions by rotating the body shape orbit in a 180 degree arc with a step and shoot modality of 30 seconds per projection with a total of 32 positions per detector, respectively, with an arc angle of difference between each projections of 5.6 degrees. The reconstruction of the SPECT tomogram was done along the sagittal, transversal and coronal axes through the region of interest using an iterative method. Radiopharmaceutical that was used was Technetium 99m labeled diphosphonate (99mTcDPD) in applied dose of $20 \mathrm{mCi}$ (740 MBq) (5). The scintigrams were examined by two independent examiners, both of whom were nuclear medicine specialists with decades of experience in interpreting BS. Positive scintigraphic findings were the existence of one or more foci with significantly enhanced radiopharmaceutical fixation, which corresponded to the existence of a skeletal osteoblastic response to the presence of a secondary deposit of PC in the skeleton. The existence of focal changes with significantly reduced fixation and with the hyperfixation rhyme was considered as the presence of osteolytic metastatic changes, or the existence of a mixed osteoblastic - osteoclastic response to the presence of hematogenous spreading of metastatic disease of $\mathrm{PC}$ in the skeleton.

Statistical processing was done with SPSS software, using descriptive testing, with cross tabulation of the obtained results. Normal and pathological value of PSA with the existence and absence of secondary deposits in the skeleton was correlated. In addition, normal and pathological value of ALP was correlated with the existence or absence of secondary deposits, and finally a combination of values of PSA and ALP was correlated with existence or absence of secondary deposits in the skeleton. The pathological values of PSA with the existence of secondary deposits on skeletal scintigraphy were consideredas true positive, the normal values of PSA with normal scintigraphic findings were considered as true negative. The false positive was the pathological value of PSA without proven metastases in the skeleton on the BS, while false negative finding was considered as the normal value of PSA with the presence of metastases on scintigraphy.

The true positive combination of PSA and ALP was the group of patients with elevated PSA and ALP values and skeletal metastases on BS, while the true negative finding was the existence of normal PSA and ALP values without skeletal metastases on BS. False positives were patients with elevated PSA and ALP without metastases on BS, whereas false negative were findings with normal PSA and ALP and with visualized metastases on scintigraphic findings. 


\section{Results}

Out of 620 patients with histologically proven PC, 349 patients had no signs of skeletal metastases
(Figure 1) and 271 patients had scintigraphic signs of secondary deposits in the skeletal system (Figure 2, 3 and 4).
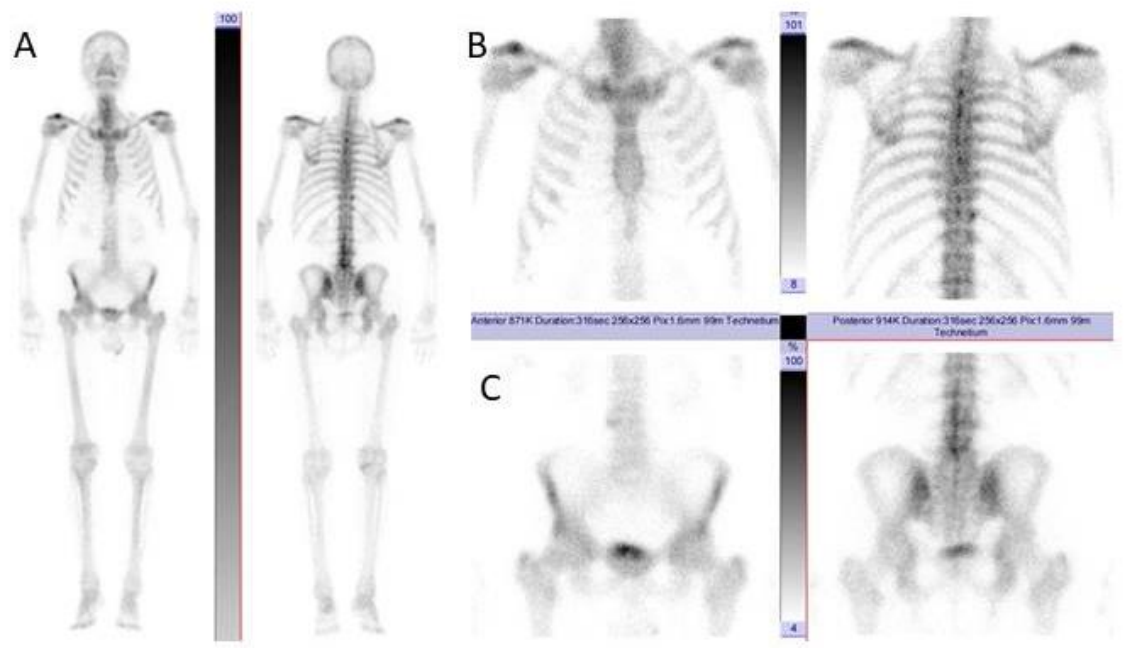

Figure 1. A. Whole body scintigraphy in anterior and posterior projections, B. Spot scintigrams of thoracic region in anterior and posterior projections, C. Spot centigrams of pelvis in anterior and posterior projections. Normal finding.
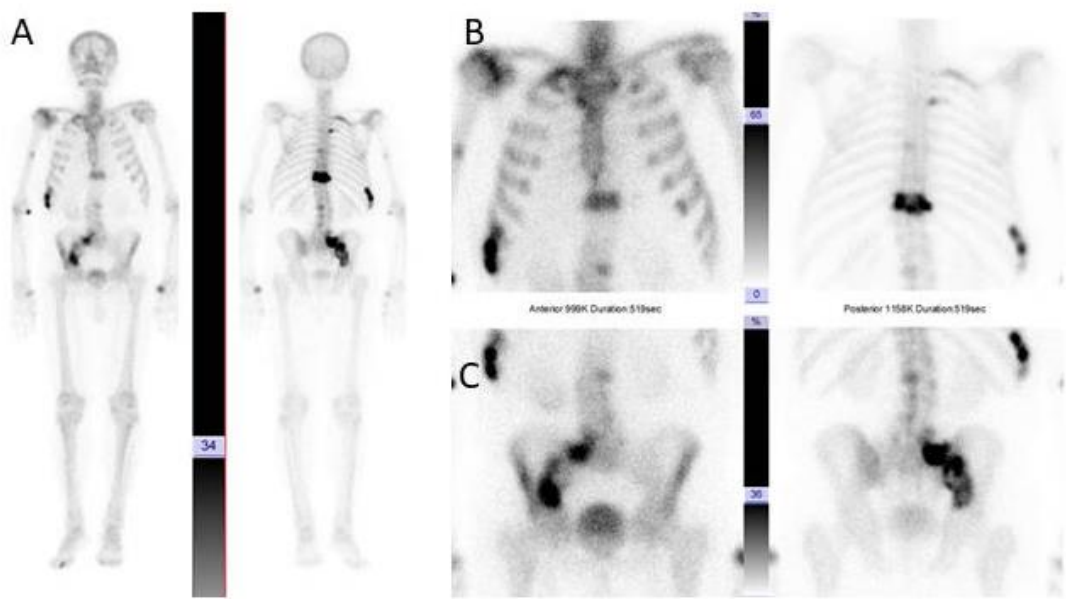

Figure 2. A. Whole body scintigraphy in anterior and posterior projections, B. Spot scintigrams of thoracic region in anterior and posterior projections, C. Spot scintgrams of pelvis in anterior and posterior projections.

Presence of metastases in the thoracic spine, posterior aspect of right sided ribs and right sacroiliac joint. 


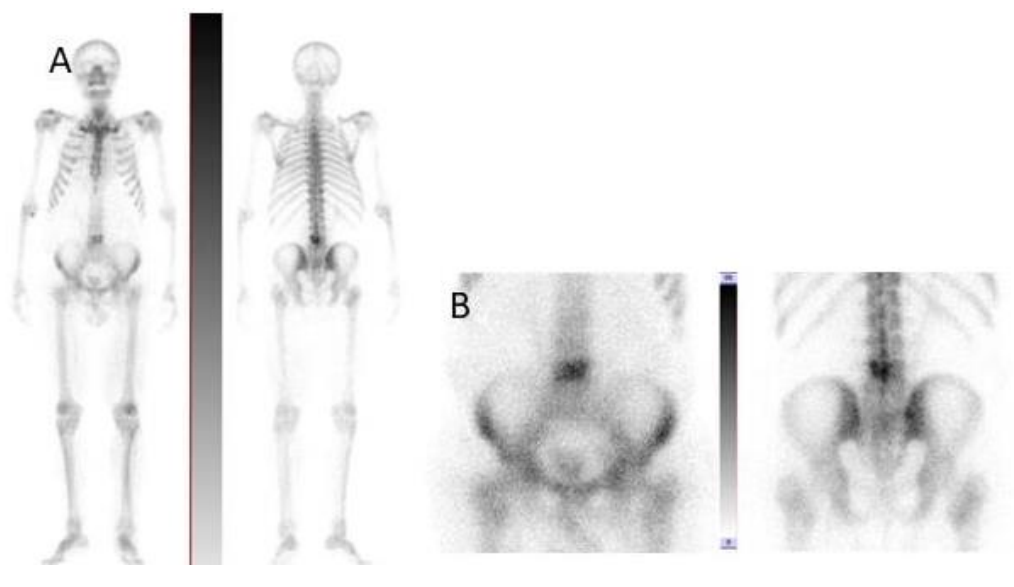

Figure 3. A. Whole body scintigraphy in anterior and posterior projections,

B. Spot scintigrams of pelvis in anterior and posterior projections. Suspect metastasis in IV lumbar vertebra.

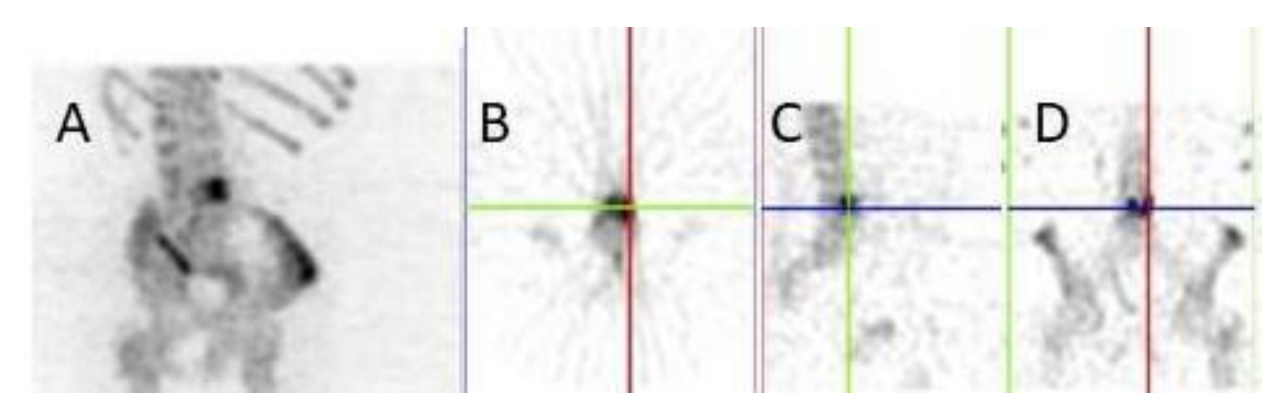

Figure 4. Patient in Figure 3. Solitary metastasis in the body of IV lumbar vertebra SPECT modality study A. Comprehensive 3D,

B. Transversal tomogram of IV lumbar vertebra,

C. Sagittal tomogram of IV lumbar vertebra,

D. Coronal tomogram of IV lumbar vertebra.

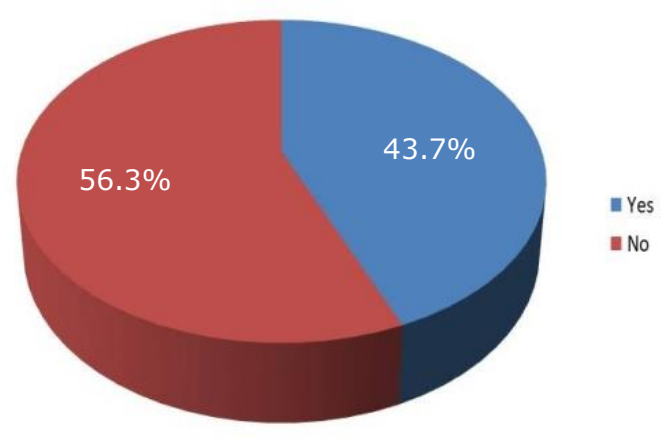

Graph 1. Existance of metastases in skeleton

Expressed in percentages, $56.3 \%$ of patients had no signs of skeletal metastases on BS, whereas
$43.7 \%$ of patients had demonstrated the existence of secondary PC deposits (Graph 1). 
Prostate specific antigen had normal values in $153(24.7 \%)$, while pathological values were found in $467(75.3 \%)$ patients (Graph 2).

Normal ALP values were found in 345 $(55.6 \%)$ patients and pathological values were found in 275 (44.4\%) (Graph 3).
Pathological values of both PSA and ALP were found in $252(40.6 \%)$ patients, pathological PSA with normal ALP values were 215 (34.7\%), normal PSA and pathological value of ALP were found in 27 (4.4\%) patients, while $126(20.3 \%)$ patients had normal values of both PSA and ALP (Graph 4).

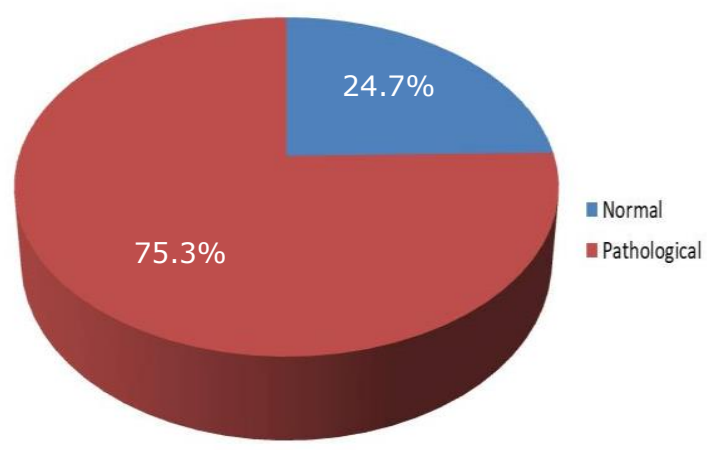

Graph 2. PSA values

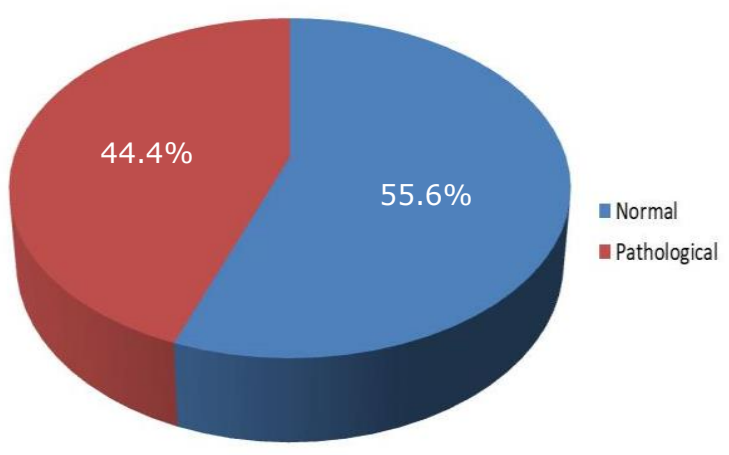

Graph 3. ALP values

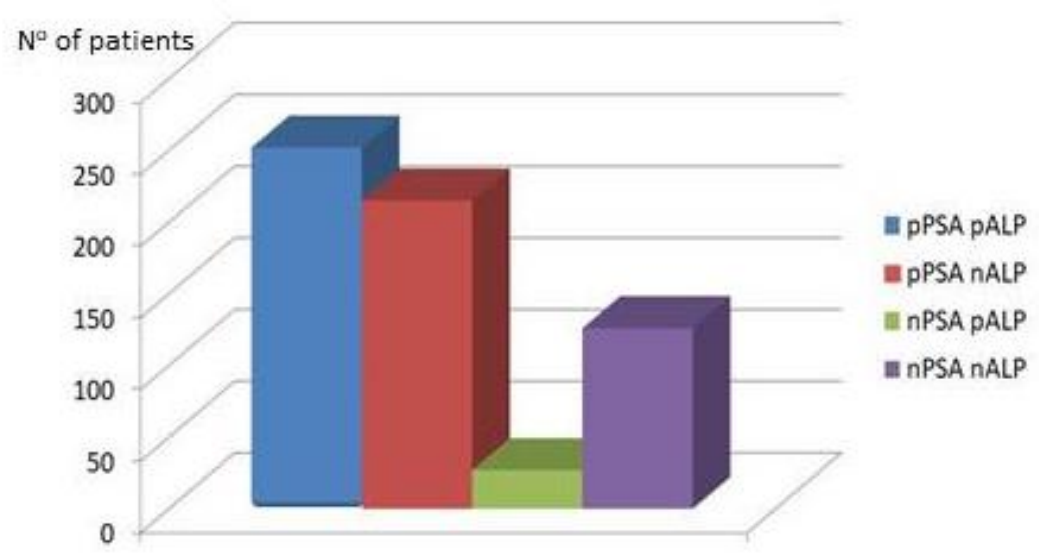

Graph 4. Combined values of PSA and ALP. $N$ - normal values, $P$ - pathological values 
Expressed over the number of patients with pathological PSA values, $53.3 \%$ of them had a positive scintigraphic finding for the existence of secondary deposits, while $(46.7 \%)$ had no skeletal metastases, while on the other hand, patients with normal PSA $(<4.0 \mathrm{ng} / \mathrm{mL})$ or low PSA values $(<10$ $\mathrm{ng} / \mathrm{mL}$ ) in $14.4 \%$ on scintigrams showed the presence of secondary deposits, while $85.6 \%$ had no skeletal metastases (Graph 5).
Three hundred forty-two patients with normal ALP values had normal BS, while in three patients with normal ALP, BS showed the existence of secondary deposits of PC. Pathological values of ALP with skeletal metastases on BS were reported in 268 patients, while pathological values of ALP without skeletal metastases were found in seven patients (Graph 6).

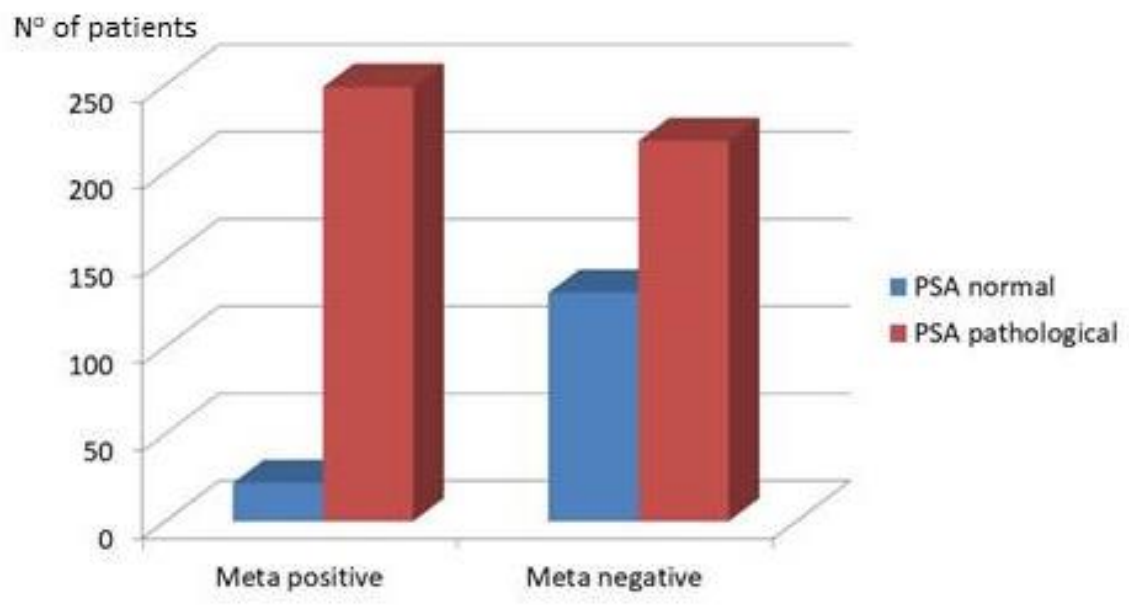

Graph 5. Existance of metastases and value of PSA

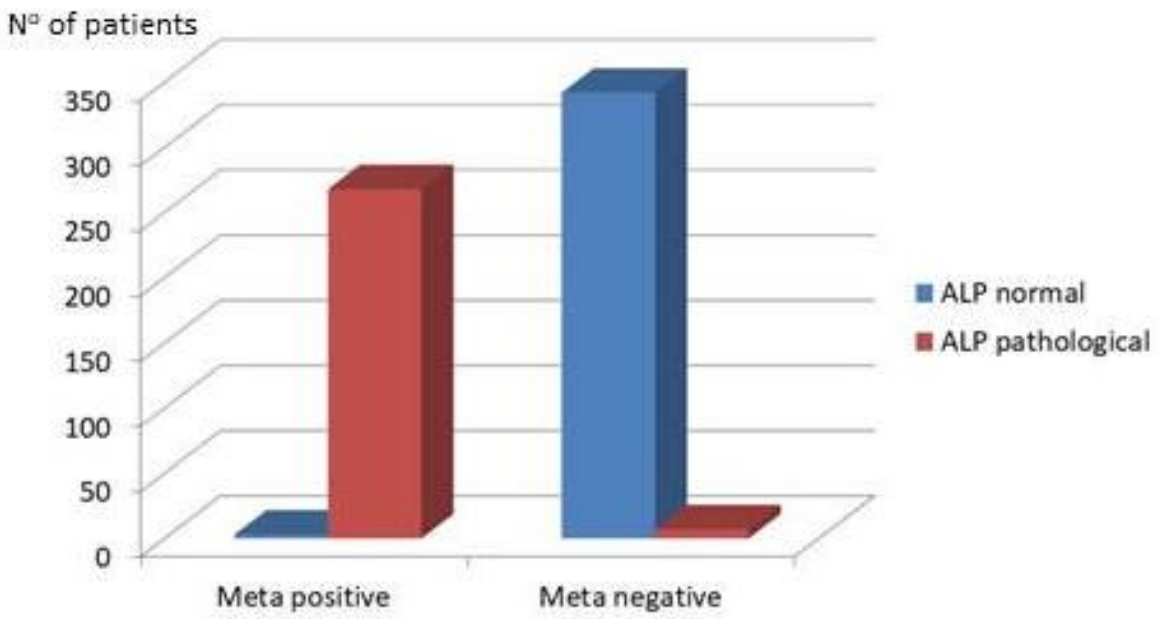

Graph 6. Existance of bone metastases and value of ALP

Pathological values of PSA and ALP were found in 252 patients, of whom 248 had skeletal metastases and 4 did not. Pathological PSA values in combination with normal ALP were observed in 215 patients, one of whom had metastases and 214 had normal BS. Normal PSA and pathological ALP were found in 27 patients, of whom 20 had metastases while 7 had normal BS. Normal PSA and ALP values were found in 126 patients, and only 2 of them had secondary deposits in the skeleton and 124 had 
normal BS. A combination of pathological values of both biological markers was considered a positive predictor of skeletal metastases, while a combination of PSA and ALP with values that were within physiological limits was considered a negative predictor (Graph 7).

Statistical processing of the obtained data yielded results that showed that serum PSA values had a sensitivity of $91.88 \%$; specificity of $37.5 \%$; a positive predictive value of $53.32 \%$; a negative predictive value of $85.62 \%$ and an overall accuracy of $61.22 \%(95 \% \mathrm{CI})$, for correlation with the existence of PC metastases on BS.

The combination of PSA and ALP was considered positive when both biological markers had pathological values, or negative, when both markers had values within the physiological range. Statistical analysis showed that the combination of PSA and ALP in correlation to the existence of PC metastases in the skeleton had a sensitivity of $99.20 \%$, specificity of $96.88 \%$, positive predictive value of $98.41 \%$, and negative predictive value of $98.41 \%$ and overall accuracy of $98.41 \%$ (95\% CI). Graph 8 shows a comparison of sensitivity, specificity, positive and negative values, and the overall accuracy of PSA as a single biological marker, and the combination of PSA and ALP together in the prediction of the existence of PC metastases in the skeleton found on BS.

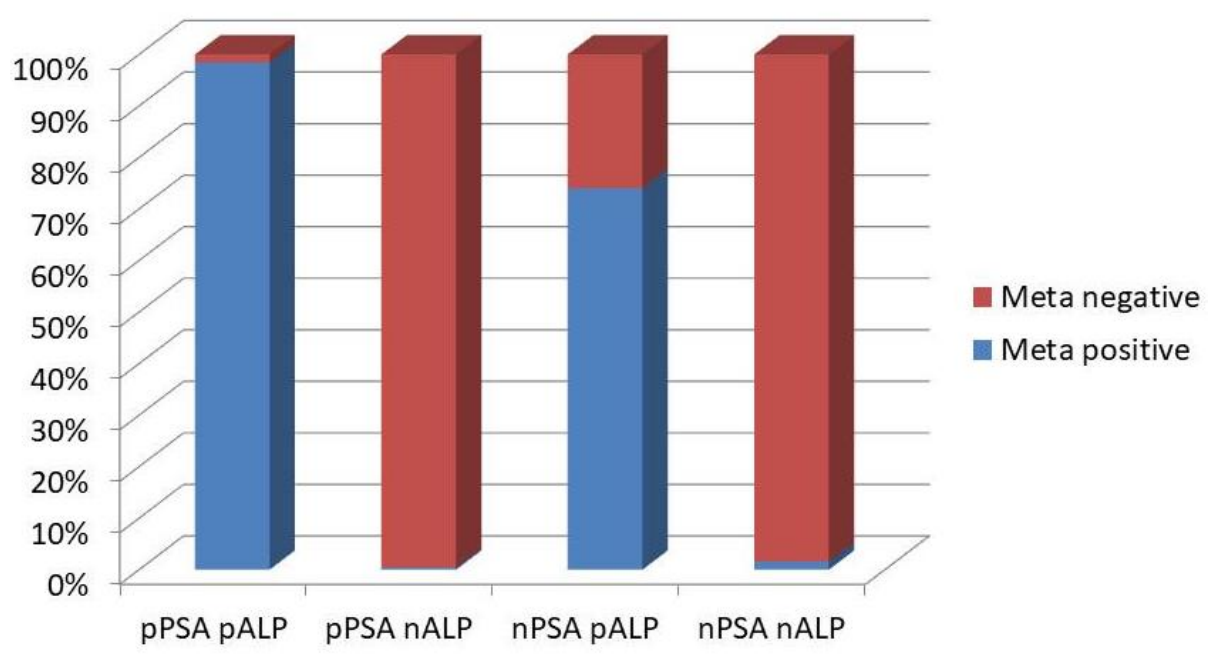

Graph 7. Combined values of PSA and ALP as positive and negative predictors for metastases on BS

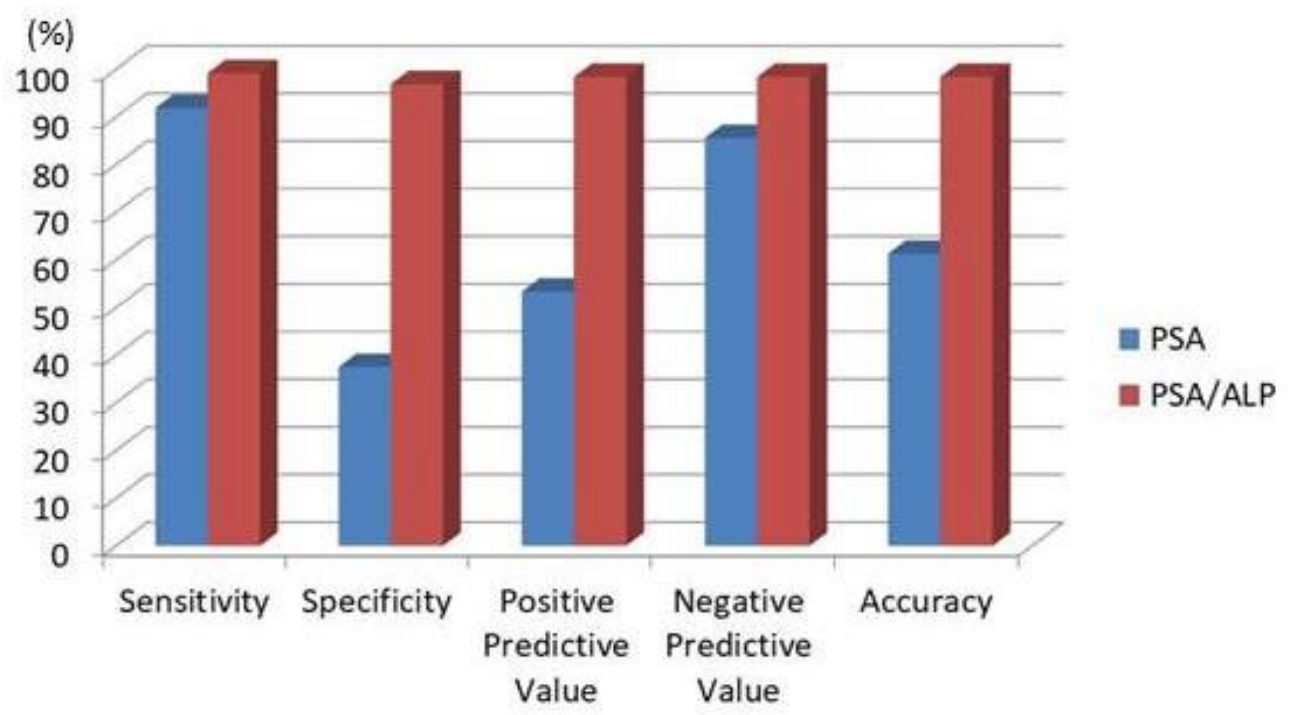

Graph 8. Comparison of PSA and combination of PSAVALP as predictors of bone metastases in patients with PC 


\section{Discussion}

Prostate adenocarcinoma ranks second in morbidity in the male population, and fifth in mortality in the total population. According to GLOBOCAN 2018 (1), there were 1,276,106 new cases of prostate adenocarcinoma reported worldwide during 2018. It has been observed that prostate cancer is more common in African-American populations with the occurrence of more severe forms of cancer, and in members of the male population over 65, regardless of race. No relevant data are yet available to indicate valid measures for the prevention of this type of cancer, and screening tests are recommended in the population over 45 years of age (6). Prostate cancer is very often an asymptomatic disease in the early stages; however, malignant prostate cancer cells migrate, penetrate the blood vessels and have a high affinity for spreading to other organs (7). Hematogenously disseminated prostate carcinoma cells have a significant affinity for expansion into the skeleton, initially engaging the axial skeleton, especially, those places in the skeleton where the red bone marrow is still active (8). The explanation for this spread of prostate cancer is that the red bone marrow represents an almost ideal substrate for the proliferation of prostate cancer cells. In autopsies, it was found that as many as $90.1 \%$ of men who died due to hematogenous spread of prostate cancer had skeletal metastases (9). The reaction of the skeleton to the presence of prostate cancer cells is reflected in the existence of osteoblastic or osteoclastic reaction of the bone, or in some cases mixed reactions to the presence of malignant cells. Osteoblastic activity is reflected practically as enhanced process of hydroxyapatite deposition, what results as the formation of a "new bone" at the sites of malignant cell nidation, without previously present bone matrix resorption. Osteolytic lesions are basically represented by the destruction of the bone matrix and this is why they result in the existence of bone softening, pain or even pathological fractures. The mixed response of the skeleton to the presence of malignant secondary deposits is in fact the simultaneous appearance of the two mechanisms described above $(10,11)$.

Prostate specific antigen is widely accepted as a screening test for early detection of prostate cancer. This approach to the initial detection of prostate cancer is still relevant today, although there are studies showing that its sensitivity to the prediction of prostate cancer is not significantly reliable. Prostate cancer has also been detected in patients who have a PSA level $<4.0 \mathrm{ng} / \mathrm{mL}$ which is considered as normal (12). Studies conducted in Australia and accepted by the National Health and Medical Research Council (NHMRC) show that it is appropriate to lower the limit of the physiological range of PSA to $<3.0 \mathrm{ng} / \mathrm{mL}$ and that even with such low PSA values, it is possible to have false negative results in the early detection of prostate cancer. Therefore, it is recommended that the testing should be adjusted to the patients' age, and that the lower recommended PSA limits depend on the age of the patients (13).
After prostate cancer is detected, one of the primary goals is to determine the suspicion of metastases in the skeleton, and after establishing the suspicion of the existence of secondary deposits of prostate cancer, to determine their presence. Years, or decades back, the authors have been trying to establish algorithms to predict the existence of hematogenous metastases of prostate cancer in the skeleton. The approaches involve the use of various biologically active markers that may indicate the existence of metastatic spread of prostate carcinoma in the skeleton.

One of the most widely used biologically active marker for screening tests in the initial diagnosis of prostate cancer is PSA, so it was a logical attempt to use the same approach, with measuring the level of PSA in patients with PC to predict the existence of bone metastases.

In a study conducted in 1996, a total of 158 prostate cancer patients reported a high negative predictive value of serum PSA of $98 \%$, its positive predictive value of $74 \%$ and an overall accuracy of $92 \%$ in the prediction of bone metastases in patients with PC. Based on the results of PSA levels and skeletal scintigraphy, it is concluded that low PSA values almost exclude the existence of metastases (14).

On the other hand, the same author who published a study in 1996 stating that low PSA values almost exclude bone metastases, two years later, published a work performed on 359 patients where the presence of metastases was detected in patients with PSA values $<10 \mathrm{ng} / \mathrm{mL}$, and concludes that PSA provides only limited information regarding the prediction of the existence of secondary deposits of prostate cancer in the skeleton (15).

In our study, the scintigraphic examination included 620 patients, of whom $43.7 \%$ had a proven presence of secondary deposits on the scintigraphic examination, while the presence of bone metastases was not scintigraphically observed in $57.3 \%$ of patients. Serum PSA levels were normal in 153 $(24.7 \%)$, whereas pathological PSA values were found in $467(75.3 \%)$ patients. In the group of patients with normal PSA values ( $<10 \mathrm{ng} / \mathrm{mL}$ ), we scintigraphically detected bone metastases in $14.4 \%$. It should be noted that patients in our study were referred for skeletal scintigraphy not only because of high PSA values but also because of a clinical picture that could indicate the presence of bone metastases of prostate cancer. Statistically, we obtained sensitivity of $91.88 \%$; specificity of $37.5 \%$; a positive predictive value of $53.32 \%$; a negative predictive value of $85.62 \%$ and an overall accuracy of $61.22 \%$ (95\% CI) for PSA levels and their relation to the existence of bone metastases. Our results are similar to those obtained in other studies, as stated by the authors in the 2012 paper in which they advocate that symptomatic patients with prostate cancer should undergo skeletal scintigraphy regardless of PSA values (16).

In addition to the clinical picture, that is, the subjective feeling of patients and the value of PSA, there is a need for more objective screening of patients diagnosed with prostate cancer in order to indicate more accurately skeletal scintigraphy for the 
purpose of detecting bone metastases. Alkaline phosphatase (ALP) in healthy humans is mainly derived from the skeleton and the liver. Elevated ALP without liver disease in patients diagnosed with prostate cancer comes from the skeleton (17).

The mechanism of occurrence of elevated ALP values in the presence of bone metastases of prostate cancer is related to the activation of osteoblastic activity in the presence of prostate cancer cells. Thus activated osteoblasts produce elevated ALP values (18). Elevated ALP values are directly related to the existence or extensiveness of secondarily depositional skeletal changes in prostate cancer, that is, a decrease in serum ALP levels is directly related to a possible improvement in metastatic disease (19). In our study, we used the opportunity to perform laboratory analysis of serum ALP levels in patients referred for skeletal scintigraphy, either because of elevated PSAs or clinically significant signs that could indicate the presence of bone metastases of prostate cancer. We combined the elevated ALP values with the elevated PSA values and then compared that battery of tests with the existence or absence of bone metastases of prostate cancer.

In our study, correlation of the existence or absence of bone metastases in the two groups of patients, one with low PSA values and ALP values in the physiological limits, and the second one with pathological values of both biological markers, showing significantly lower number of patients with
PC bone metastases in the group with low values of PSA and ALP. On the other side, in the group of patients with pathological values of PSA and ALP, BS showed significantly higher number of patients with presence of PC bone metastases.

\section{Conclusion}

Prostate specific antigen as an independent biological marker in terms of prediction of bone metastasis in prostate cancer patients showed significantly lower sensitivity, specificity, positive and negative predictive value, and overall accuracy compared to the combination of PSA and ALP.

As part of the evaluation of patients diagnosed with prostate cancer in order to more accurately indicate skeletal scintigraphy for the detection of bone metastases, a combination of serum PSA, ALP, and clinical signs suggesting bone metastasis should be used according to our results.

Such an approach reduces the number of patients who would be unnecessarily referred to skeletal scintigraphy, and on the other side, the number of patients who, due to possibly low or moderately elevated PSA values as a standalone marker, with skeletal metastases, remain with no admission to bone scintigraphy and consequently without detection of existing metastatic changes. 


\section{References}

1. Bray F, Ferlay J, Soerjomataram I, Siegel RL, Torre LA, Jemal A. Global cancer statistics 2018: GLOBOCAN estimates of incidence and mortality worldwide for 36 cancers in 185 countries. CA Cancer J Clin 2018;68 (6): 394-424. [CrossRef] [PubMed]

2. Nørgaard M, Jensen AØ, Jacobsen JB, Cetin K, Fryzek JP, Sørensen HT. Skeletal related events, bone metastasis and survival of prostate cancer: a population based cohort study in Denmark (1999 to 2007). J Urol 2010;184(1): 162-7. [CrossRef] [PubMed]

3. Brown JE, Sim S. Evolving role of bone biomarkers in castration-resistant prostate cancer. Neoplasia 2010; 12(9):685-96. [CrossRef] [PubMed]

4. Van den Wyngaert $T$, Strobel $K$, Kampen WU, Kuwert $T$, van der Bruggen $W$, Mohan HK, et al. The EANM practice guidelines for bone scintigraphy. Eur J Nucl Med Mol Imaging 2016;43(9):1723-38. [CrossRef] [PubMed]

5. Mettler Jr FA, Huda W, Yoshizumi TT, Mahesh M. Effective doses in radiology and diagnostic nuclear medicine: a catalog. Radiology 2008;248:254-63. [CrossRef] [PubMed]

6. Rawla P. Epidemiology of Prostate Cancer. World J Oncol 2019;10(2):63-89. [CrossRef] [PubMed]

7. Wong SK, Mohamad NV, GiazeTR, Chin KY, Mohamed N, Ima-Nirwana S. Prostate Cancer and Bone Metastases: The Underlying Mechanisms. Int J Mol Sci 2019;20(10):2587 [CrossRef] [PubMed]

8. Bagi C. Skeletal implications of prostate cancer. J Musculoskelet Neuronal Interact 2003;3:112-117. [PubMed]

9. Bubendorf L, Schöpfer A, Wagner U, Sauter G, Moch $\mathrm{H}$, Willi $\mathrm{N}$, et al. Metastatic patterns of prostate cancer: An autopsy study of 1,589 patients. Hum Pathol 2000;31:578-83. [CrossRef] [PubMed]

10. RoodmanGD. Mechanisms of bone metastasis. N Engl J Med 2004;350:1655-64. [CrossRef] [PubMed]

11. Westendorf] J, Kahler RA, Schroeder TM. Wht signaling in osteoblasts and bone diseases. Gene 2004; 341:19-3. [CrossRef] [PubMed]
12. Thompson IM, Pauler DK, Goodman PJ, Tangen CM, Lucia MS, Parnes HL et al. Prevalence of prostate cancer among men with a prostate-specific antigen level $<$ or $=4.0 \mathrm{ng}$ per milliliter. $\mathrm{N}$ Engl J Med 2004; 350(22):2239-46. [CrossRef] [PubMed]

13. Cabarkapa S, Perera M, McGrath S, Lawrentschuk N. Prostate cancer screening with prostate-specific antigen: A guide to the guidelines. Prostate Int 2016; 4(4):125-9. [CrossRef] [PubMed]

14. Wolff JM, Bares R, Jung PK, Buell U, Jakse G. Prostatespecific antigen as a marker of bone metastasis in patients with prostate cancer. Urol Int 1996;56(3): 169-73. [CrossRef] [PubMed]

15. Wolff JM, Zimny M, Borchers $H$, Wildberger J, Buell $U$, Jakse $\mathrm{G}$. Is prostate-specific antigen a reliable marker of bone metastasis in patients with newly diagnosed cancer of the prostate? Eur Urol 1998;33(4):376-81. [CrossRef] [PubMed]

16. KamaleshwaranKK, Mittal BR, Harisankar CN, Bhattacharya A, Singh SK, Mandal AK. Predictive value of serum prostate specific antigen in detecting bone metastasis in prostate cancer patients using bone scintigraphy. Indian J Nucl Med 2012;27(2):81-4. [CrossRef] [PubMed]

17. Cook RJ, Coleman R, Brown J, Lipton, A, Major, P, Hei $Y$ J et al. Markers of bone metabolism and survival in men with hormone-refractory metastatic prostate cancer. Clin Cancer Res 2006;12(11 Pt 1):3361-67. [CrossRef] [PubMed]

18. Rucci N, Teti A. Osteomimicry: how tumor cells try to deceive the bone. Front Biosci (Schol Ed) 2010;2: 907-15. [CrossRef] [PubMed]

19. D'Oronzo S, Brown J, Coleman R. The value of biomarkers in bone metastasis. Eur J Cancer Care (Engl). 2017;26(6):10.1111/ecc.12725. [CrossRef] [PubMed] 


\title{
PROSTATA SPECIFIČNI ANTIGEN U ODNOSU NA KOMBINACIJU PROSTATA SPECIFIČNOG ANTIGENA I ALKALNE FOSFATAZE U PREDIKCIJI SCINTIGRAFSKI DETEKTOVANIH METASTAZA KARCINOMA PROSTATE
}

\author{
Miloš Stević1,2, Marina Vlajković1,2, Marko Kojić1, Filip Veličković ${ }^{1}$, Nina Topić1, \\ Dragoslav Bašićc 2,3
}

${ }^{1}$ Klinički centar Niš, Centar za nuklearnu medicinu, Niš, Srbija

${ }^{2}$ Univerzitet u Nišu, Medicinski fakultet, Niš, Srbija

${ }^{3}$ Klinički centar Niš, Klinika za urologiju, Niš, Srbija

Kontakt: Miloš Stević

Prešernova 8/68, 18000 Niš, Srbija

E-mail: mlsstvc@gmail.com

\begin{abstract}
Karcinom prostate (CP) na drugom je mestu po broju obolelih i po mortalitetu u populaciji muškaraca starosti preko 50 godina i ima veliki afinitet prema metastaziranju u koštani sistem. Cilj ovog rada bilo je utvrđivanje prediktivne vrednosti prostata specifičnog antigena (PSA) u odnosu na kombinaciju PSA i alkalne fosfataze (ALP) u predikciji postojanja scintigrafski detektabilnih metastaza CP. U studiju je bilo uključeno 620 bolesnika sa patohistološki dokazanim CP, koji su na scintigrafiju upućivani zbog povišenih vrednosti PSA, ALP ili zbog kliničkih znakova, koji bi mogli da ukazuju na postojanje koštanih metastaza CP. Scintigrafija skeleta (BS) rađena je po ustaljenom protokolu Evropske asocijacije nuklearne medicine (EANM). Statistička obrada podataka podrazumevala je procenu specifičnosti, senzitivnosti, pozitivne i negativne prediktivne vrednosti i ukupne tačnosti PSA i kombinacije PSA i ALP u predikciji postojanja scintigrafski detektabilnih koštanih metastaza CP. U pogledu predikcije postojanja koštanih metastaza na BS, PSA je pokazao senzitivnost u iznosu od $91,88 \%$; specifičnost u iznosu od $37,5 \%$; pozitivnu prediktivnu vrednost u iznosu od $53,32 \%$; negativnu prediktivnu vrednost u iznosu od $85,62 \%$ i ukupnu tačnost u iznosu od $61,22 \%$ (95\% CI). Kombinacija PSA i ALP pokazala je senzitivnost od 99,20\%, specifičnost od $96,88 \%$, pozitivnu prediktivnu vrednost od $98,41 \%$, negativnu prediktivnu vrednost od $98,41 \%$ i ukupnu tačnost od $98,41 \%$ ( $95 \%$ CI). Kombinacija PSA i ALP pokazala je signifikantno veću senzitivnost, specifičnost, pozitivnu i negativnu prediktivnu vrednost, odnosno ukupnu tačnost u odnosu na PSA, kao samostalni biološki marker. Prilikom indikovanja BS, kod bolesnika sa CP treba uzeti u obzir vrednosti PSA, ALP i kliničke znake u cilju rane detekcije koštanih metastaza i izbegavanja nepotrebnog upućivanje na scintigrafiju bolesnika, kod kojih ne postoji visoka sumnja na postojanje koštanih metastaza.
\end{abstract}

Acta Medica Medianae 2020;59(3):73-83.

Ključne reči: prostata specifični antigen, alkalna fosfataza, scintigrafija skeleta 